\title{
ANALISIS LIKUIDITAS BERBASIS LAPORAN KEUANGAN BRI SYARIAH TAHUN 2013 - 2015
}

\author{
Abdul Haris Romdhoni \\ STIE-AAS Surakarta \\ Email: harisromdhoni27@yahoo.com
}

\begin{abstract}
This study aims to examine the liquidity of financial ratios. Liquidity became quite urgent, because liquidity is the ability of a company to meet its obligations in the short term. It was often a problem in some companies or banks. Liquidity for year 2013-2015 BRI Syariah good enough because the current assets by current liabilities are divided proportionally, so that if there is no short-term obligations will be fulfilled by the ratio of current assets are quite liquid.
\end{abstract}

Keywords: liquidity, financial ratios and financial performance.

\section{PENDAHULUAN}

Dua dasawarsa terakhir ini lembaga keuangan baik bank maupun non-bank berkembang cukup cepat dan pesat. Lembaga keuangan tersebut juga memiliki berbagai variasi dalam berbagai prinsip implementasi, baik syariah maupun konvensional. Dengan berkembangnya waktu banyak lembaga keuangan membuka cabang di penjuru pelosok tanah air.

Lembaga keuangan utamanya perbankan memiliki peran yang sangat strategis. Peran tersebut dapat menggerakkan roda perekonomian nasional melalui penghimpunan dana dan penyaluran dana. Penghimpunan dana melalui berbagai varian produk tabungan dan deposito. Sedangkan dalam penyaluran dana bank memberikan fasilitas pinjaman dalam berbagai bentuk pula.
Melihat peran bank dalam bidang keuangan maka, dalam hal ini Bank Indonesia (BI) dan Otoritas Jasa Keuangan (OJK) bertanggung jawab dalam pembinaan dan pegawasan operasionalisasi bank. Tidak mengherankan jika BI dan OJK meminta setiap bulan maupun tahun untuk melaporkan kondisi keuangannya. Dengan laporan keuangan dapat dijadikan sebagai snapshot kondisi perbankan secara mikro yang kemudian digunakan sebagai kebijakan dalam perekonomian. Dengan laporan keuangan pula dapat dilihat kinerja atau rasio keuangan dari bank tersebut.

Rasio sendiri adalah menggambarkan suatu hubungan atau perimbangan (mathematical relationship) antara suatu jumlah tertentu dengan jumlah yang lain (Munawir, 2000:54). Rasio sebenarnya adalah alat yang dinyatakan dalam aritmathical terms yang dapat digunakan untuk menjelaskan hubungan antara dua macam data finansial (Bambang 
Riyanto, 2001:329). Rasio keuangan merupakan suatu informasi yang menggambarkan hubungan antara berbagai macam akun (accounts) dari laporan keuangan yang mencerminkan keadaan keuangan serta hasil operasional perusahaan. Sedangkan studi yang berfungsi untuk mempelajari rasio keuangan tersebut disebut analisa rasio keuangan (financial ratios analysis)..

Dari rasio keuangan dapat digunakan untuk mengetahui tingkat kesehatan keuangan suatu bank diperlukan alat-alat analisa finansiil. Diantara alat finansiil yang digunakan adalah analisa rasio. Umumnya analisa rasio yang digunakan untuk mengukur kesehatan finansiil suatu perusahaan adalah analisa rasio rentabilitas, likuiditas, solvabilitas ini merupakan indikator utamanya sedangkan indikator tambahan terdiri dari profit margin, rasio operasi, dan produktivitas tenaga kerja. Menurut Bambang Riyanto (2001), analisis rasio likuiditas adalah rasio yang digunakan untuk mengetahui kemampuan perusahaan untuk membayar hutang-hutang dalam jangka pendek. Sedangkan solvabilitas adalah kemampuan perusahaan untuk memenuhi seluruh kewajiban perusahaan baik jangka pendek maupun jangka panjang. Sementara rentabilitas adalah perbandingan antara laba dan aktiva atau modal yang menghasilkan laba. Berdasar pemikiran diatas dan mengingat pentingnya kinerja keuangan maka dalam penelitian ini akan meneliti tentang Analisis Likuiditas Berbasis Laporan Keuangan BRI Syariah Tahun 2013-2015

\section{Rumusan Masalah}

Permasalahan dalam penelitian ini dapat dirumuskan sebagai berikut :

1. Bagaimanakah perkembangan kinerja keuangan (likuiditas) BRI Syariah Tahun 2013-2015 ?

2. Apakah kinerja keuangan (likuiditas) BRI Syariah Tahun 2013-2015 bergerak positif atau negatif?

\section{Tujuan Penelitian}

1. Untuk mengetahui perkembangan kinerja keuangan (likuiditas) BRI Syariah Tahun 2013-2015.

2. Untuk mengetahui kinerja keuangan (likuiditas) BRI Syariah Tahun 20132015 bergerak positif atau negatif.

\section{LANDASAN TEORI Pengertian Bank}

Di Indonesia telah beroperasi dua sistem perbankan yaitu perbankan konvensional dan perbankan syariah. Perbankan syariah operasionalisasinya relatif baru terhitung sejak tahun 1992 dengan didirikannya Bank Muamalat Indonesia. Sementara perbankan konvensional sudah sejak lama beroperasi.

Dahlan (1999) mengemukakan bank dapat didefinisikan sebagai badan usaha yang kegiatan utamanya adalah menerima simpanan dari masyarakat dan atau dari pihak lainnya, kemudian mengalokasikan kembali untuk memperoleh keuntungan serta menyediakan jasa-jasa dalam lalulintas pembayaran.

Menurut Undang-Undang No. 21 tahun 2008 tentang Perbankan Syariah pada pasal 1, dijelaskan bahwa perbankan syariah adalah: "segala sesuatu yang 
menyangkut tentang Bank Syariah dan Unit Usaha Syariah, mencakup kelembagaan, kegiatan usaha, serta cara dan proses dalam melaksanakan kegiatan usahanya". Sedangkan pengertian bank syariah : adalah bank yang menjalankan usahanya berdasarkan prinsip syariah dan menurut jenisnya terdiri atas Bank Umum Syariah dan Bank Pembiayaan Rakyat Syariah". Secara prinsip perbedaan antara bank konvensional dengan bank syariah dapat dilihat dalam tabel berikut :

Tabel Perbedaan Bank Konvensional dengan Bank Syariah

\begin{tabular}{|c|c|}
\hline Bank Syari'ah & Bank Konvensional \\
\hline $\begin{array}{l}\text { a. Berdasarkan prinsip investasibagi hasil } \\
\text { b. Menggunakan prinsip jual-beli } \\
\text { c. Hubungan dengan nasabah dalam } \\
\text { bentukhubungan kemitraan } \\
\text { d. Melakukan investasi-investasiyang halal saja } \\
\text { e. Setiap produk dan jasa yangdiberikan sesuai } \\
\text { dengan fatwaDewan Syari'ah } \\
\text { f. Dilarangnya gharar dan maisir } \\
\text { g. Menciptakan keserasian diantara keduanya. } \\
\text { h. Tidak memberikan dana secara tunai tetapi } \\
\text { memberikan barang yang dibutuhkan (finance } \\
\text { thegoods and services) } \\
\text { i. Bagi hasil menyeimbangkan sisipasiva dan } \\
\text { aktiva. }\end{array}$ & $\begin{array}{l}\text { a. Berdasarkan tujuan membungakan uang } \\
\text { b. Menggunakan prinsip pinjammeminjam uang. } \\
\text { c. Hubungan dengan nasabah dalam bentuk hubungan } \\
\text { kreditur-debitur } \\
\text { d. Investasi yang halal maupun yang haram } \\
\text { e. Tidak mengenal Dewan sejenis itu. } \\
\text { f. Terkadang terlibat dalam speculative FOREX } \\
\text { dealing } \\
\text { g. Berkontribusi dalam terjadinya kesenjangan antara } \\
\text { h. Mektor riel dengan sektor moneter. } \\
\text { i. } \text { streaming (penyalahgunaan dana pinjaman) }\end{array}$ \\
\hline
\end{tabular}

Sumber: Antonio (2001)

\section{Laporan Keuangan}

\section{Menurut Ghozali dan Chariri} (2003) laporan keuangan merupakan salah satu sumber data untuk mengukur kinerja perusahaan. Laporan keuangan merupakan bagian dari proses pelaporan keuangan yang bertujuan untuk menyediakan informasi tentang posisi keuangan, kinerja, dan arus kas perusahaan yang bermanfaat bagi sebagian besar kalangan penggunaan laporan keuangan dalam rangka pembuatan keputusan-keputusan ekonomi serta menunjukkan pertanggung jawaban manajemen atas penggunaan sumbersumber daya yang dipercayakan pada mereka.
Laporan keuangan akan dibutuhkan dan berguna untuk berbagai pihak yang membutuhkannya, baik dari internal maupun eksternal. Sementara Baridwan (2004:17) mendefinisikan laporan keuangan merupakan ringkasan dari suatu proses pencatatan, merupakan suatu ringkasan dari taransaksi-transaksi keuangan yang terjadi selama tahun buku yang bersangkutan.

\section{Analisis Laporan Keuangan}

Analisis laporan keuangan (financial statement analysis) adalah aplikasi dari alat dan teknik analitis untuk laporan keuangan bertujuan umum dan data-data yang berkaitan untuk menghasilkan estimasi dan kesimpulan 
yang bermanfaat dalam analisis bisnis. Analisis laporan keuangan mengurangi ketergantungan pada firasat, tebakan, dan intuisi dalam pengambilan keputusan. Analisis ini mengurangi ketidakpastian analisis bisnis. Analisis ini tidak mengurangi perlunya penilaian ahli, namun menyediakan dasar yang sistematis dan efektif untuk analisis bisnis (Wild et al., 2008:3-4).

Dengan analisis laporan keuangan akan membantu sejauh mana kondisi keuangan suatu bank mengalami perkembangan. Munawir (2010:35) menambahkan analisis laporan keuangan adalah analisis laporan keuangan yang terdiri dari penelaahan atau mempelajari daripada hubungan dan tendensi atau kecenderungan (trend) untuk menentukan posisi keuangan dan hasil operasi serta perkembangan perusahaan yang bersangkutan.

\section{Kinerja Keuangan}

Menurut Mulyadi (1997), Kinerja perusahaan (bank) adalah suatu tampilan perusahaan selama periode waktu tertentu, untuk mengetahui kondisi kinerjanya, maka perusahaan dapat melakukannya dengan menilai kinerja perusahaannya dan penilaian kinerja adalah penentuan secara periodik efektifitas suatu organisasi, bagan organisasi dan karyawannya berdasarkan sasaran, standar dan kriteria yang telah ditetapkan sebelumnya. Sementara menurut (Standar Akutansi Keuangan : 2001) kinerja suatu perusahaan atau bank dapat dirumuskan sebagai hasil kerja yang diperoleh atas kegiatan atau operasi yang dilakukan oleh perusahaan selama periode waktu tertentu dan laba merupakan salah satu tolak ukur penting dalam penilaian kinerja perusahaan atau bank.

\section{Likuiditas}

Pengertian rasio likuiditas menurut Darsono, et al. (2004: 51) adalah rasio yang bertujuan untuk mengetahui kemampuan perusahaan dalam membayar kewajiban jangka pendek. Likuiditas merupakan gambaran kemampuan perusahaan untuk menyelesaikan kewajiban jangka pendeknya. Astuti (2004: 31) menambahkan, posisi likuiditas perusahaan menunjukan kemampuan perusahaan memenuhi kewajiban jangka pendeknya.

Rasio-rasio ini dapat dihitung melalui sumber informasi tentang modal kerja yaitu pos-pos aktiva lancar dan utang lancar. Current Ratio merupakan salah satu rasio likuiditas. Current Ratio menunjukkan tingkat keamanan (margin of safety) kreditor jangka pendek. Dengan adanaya current ratio yang tinggi belum tentu menjamin akan dapat dibayarnya utang perusahaan yang sudah jatuh tempo karena proporsi atau distribusi dari aktiva lancar yang tidak menguntungkan (Munawir, 2004).

Rasio likuiditas dapat dibuat dalam bentuk berapa kali atau dalam bentuk prosentase. Apabila rasio lancar ini 1:1 atau $100 \%$, ini berarti bahwa aktiva lancar dapat menutupi semua utang lancar. Rasio lancar yang lebih aman adalah jika berada di atas 1 atau di atas 100\% (Harahap, 1998:301). Hal yang paling penting dalam mengukur rasio modal kerja (rasio likuiditas) bukanlah pada besar kecilnya perbedaan aktiva lancar dengan utang 
jangka pendek, melainkan harus dilihat pada hubungannya atau perbandingannya yang mencerminkan kemampuan mengembalikan utang. Current ratio yang tinggi mungkin menunjukkan adanya uang kas yang berlebihan dibandingkan dengan tingkat kebutuhan atau adanya unsur aktiva lancar yang rendah likuiditasnya (seperti persediaan) yang berlebihan. Current ratio yang tinggi tersebut memang baik dari sudut pandang kreditor, namun dari sudut pandang investor, hal ini kurang menguntungkan karena aktiva lancar tidak didayagunakan dengan efektif. Sebaliknya, current ratio yang rendah relatif lebih riskan, namun menunjukkan bahwa manajemen telah mengoperasikan aktiva lancar secara efektif (Djarwanto, 2004:150).

\section{METODE PENELITIAN}

\section{Variable Penelitian}

Menurut Arikunto (1998:91) variable penelitian yaitu obyek penelitian atau apa yang menjadi titik perhatian suatu penelitian. Dalam penelitian ini variable yang ada adalah variable independen yaitu rasio keuangan dan variable dependen yaitu Rasio Lancar Current Ratio, Rasio Cepat / Quick Ratio dan Quick Ratio.

\section{Populasi dan Sampel}

Populasi dalam penelitian ini adalah BRI Syariah yang menyajikan laporan keuangan selama tahun 2013-2015.

\section{Jenis dan Sumber Data}

Jenis data yang digunakan dalam penelitian ini adalah data sekunder yang sumber datanya diperoleh dari Laporan Keuangan BRI Syariah tahun 2013-2015 melalui web : www.brisyariah.co.id di akses pada tanggal 20 Januari 2017.

\section{Alat Analisis}

Likuiditas berhubungan dengan masalah kepercayaan kreditor jangka pendek kepada perusahaan yang ditunjukan oleh besar kecilnya aktiva lancar. Rasio likuiditas, antara lain sebagai berikut:

a. Current ratio adalah kemampuan perusahaan untuk memenuhi kewajiban yang harus segera dipenuhi atau dengan kata lain untuk memenuhi kewajiban jangka pendeknya (Machfoedz, 1999 dalam Putra, tt). Current ratio $=\frac{\text { Aktiva Lancar }}{\text { Hutang Lancar }} \times 100 \%$

b. Quick ratio adalah perbandingan aktiva lancar dikurangi persediaan dengan hutang lancar (Munawir, 2001).

$$
\text { Quick Ratio }=\frac{\text { Kas }- \text { Persediaan }}{\text { Hutang Lancar }} \times 100 \%
$$

c. Cash ratio adalah perbandingan antara kas dengan total hutang lancar (Munawir,2001)

$$
\text { Cash Ratio }=\frac{\text { Kas }}{\text { Total Hutang Lancar }} X 100 \%
$$

\section{PEMBAHASAN}

\section{Kinerja Keuangan pada BRI Syariah}

Menurut Mulyadi (1997), Kinerja perusahaan (bank) adalah suatu tampilan perusahaan selama periode waktu tertentu, untuk mengetahui kondisi kinerjanya, maka perusahaan dapat melakukannya dengan menilai kinerja perusahaannya dan penilaian kinerja adalah penentuan secara periodik efektifitas suatu organisasi, bagan 
organisasi dan karyawannya berdasarkan sasaran, standar dan kriteria yang telah ditetapkan sebelumnya.

Sementara menurut (Standar Akutansi Keuangan : 2001) kinerja suatu perusahaan atau bank dapat dirumuskan sebagai hasil kerja yang diperoleh atas kegiatan atau operasi yang dilakukan oleh perusahaan selama periode waktu tertentu dan laba merupakan salah satu tolak ukur penting dalam penilaian kinerja perusahaan atau bank.

\section{Likuiditas pada BRI Syariah}

Pengertian rasio likuiditas menurut Darsono, et al. (2004: 51) adalah rasio yang bertujuan untuk mengetahui kemampuan perusahaan dalam membayar kewajiban jangka pendek. Likuiditas merupakan gambaran kemampuan perusahaan untuk menyelesaikan kewajiban jangka pendeknya. Astuti (2004: 31) menambahkan, posisi likuiditas perusahaan menunjukan kemampuan perusahaan memenuhi kewajiban jangka pendeknya.

Rasio-rasio ini dapat dihitung melalui sumber informasi tentang modal kerja yaitu pos-pos aktiva lancar dan utang lancar. Current Ratio merupakan salah satu rasio likuiditas. Current Ratio menunjukkan tingkat keamanan (margin of safety) kreditor jangka pendek. Dengan adanaya current ratio yang tinggi belum tentu menjamin akan dapat dibayarnya utang perusahaan yang sudah jatuh tempo karena proporsi atau distribusi dari aktiva lancar yang tidak menguntungkan (Munawir, 2004).

Rasio likuiditas dapat dibuat dalam bentuk berapa kali atau dalam bentuk prosentase. Apabila rasio lancar ini 1:1 atau $100 \%$, ini berarti bahwa aktiva lancar dapat menutupi semua utang lancar. Rasio lancar yang lebih aman adalah jika berada di atas 1 atau di atas 100\% (Harahap, 1998:301). Hal yang paling penting dalam mengukur rasio modal kerja (rasio likuiditas) bukanlah pada besar kecilnya perbedaan aktiva lancar dengan utang jangka pendek, melainkan harus dilihat pada hubungannya atau perbandingannya yang mencerminkan kemampuan mengembalikan utang. Current ratio yang tinggi mungkin menunjukkan adanya uang kas yang berlebihan dibandingkan dengan tingkat kebutuhan atau adanya unsur aktiva lancar yang rendah likuiditasnya (seperti persediaan) yang berlebihan. Current ratio yang tinggi tersebut memang baik dari sudut pandang kreditor, namun dari sudut pandang investor, hal ini kurang menguntungkan karena aktiva lancar tidak didayagunakan dengan efektif. Sebaliknya, current ratio yang rendah relatif lebih riskan, namun menunjukkan bahwa manajemen telah mengoperasikan aktiva lancar secara efektif (Djarwanto, 2004:150).

Berdasar laporan keuangan dari BRI Syariah kinerja keuangan pada likuiditas aktiva lancar mengalami peningkatan, dengan demikian BRI Syariah memiliki aktiva yang likuid untuk membiayai jangka pendek apabila ada kewajiban yang harus diselesaikan.

\begin{tabular}{|c|c|c|}
\hline 2013 & 2014 & 2015 \\
\hline $102.70 \%$ & $93.90 \%$ & $84.16 \%$ \\
\hline
\end{tabular}




\section{KESIMPULAN}

Berdasar analisis kinerja keuangan di atas bahwa kinerja keuangan BRI Syariah Tahun 2013-2015 adalah sebagai berikut :

1. Kinerja keuangan BRI Syariah menunjukkan kecendrungan yang positif, sehingga dari sisi likuiditas dalam memenuhi kewajiban jangka pendek cukup baik.

2. Likuiditas BRI Syariah perlu ditingkatkan dari komponenkomponen yang dapat memperkuat likuiditas.

\section{DAFTAR PUSTAKA}

Bambang Riyanto, 2001. Dasar-dasar Pembelanjaan Perusahaan, Edisi Keempat, Yogyakarta: BPFE.

Baridwan, Zaki. 2008. Intermediate Accounting. Edisi delapan. Cetakan kedua. BPFE-Yogyakarta.

Harahap, Sofyan Syafri. 1998. Analisa Kritis atas Laporan Keuangan. Jakarta: PT Rajagrafindo Persada.

Ikatan Akuntan Indonesia, 2001. Standar Akutansi Keuangan, Jakarta: Salemba Empat.

Imam Ghozali dan Anis Chariri, 2003. Teori Akuntansi, Semarang: Badan Penerbit Universitas Diponegoro.

Martono, dan Harjito, Agus. 2008. Manajemen Keuangan, Yogyakarta: EKONISIA.
Mulyadi, 1997. Akutansi Manajemen ( Konsep, Manfaat dan Rekayasa ), Edisi Kedua, Yogyakarta: Bagian Penerbitan STIE YKPN.

Munawir S, 1999. Analisa Laporan Keuangan, Yogyakarta: Karunia Liberty.

Putra, Nanda Budia, (Tanpa Tahun) Analisis Kinerja Keuangan Pada Pt. Antam Tbk, Periode Tahun 2007-2011, Departemen Akuntansi, Fakultas Ekonomi Universitas Gunadarma

Riyanto, 2001, Bambang. Dasar-Dasar Pembelanjaan Perusahaan, Yogyakarta: BPFE.

Hartono, Jogiyanto. 2008. Teori Portofolio dan Analisis Investasi. Edisi Kelima. Yogyakarta: BPFE.

Astuti, Dewi. 2004. Manajemen Keuangan Perusahaan, Edisi Pertama. Penerbit.Ghalia Indonesia.

Djarwanto. 1993. Pokok - pokok Analisa Laporan Keuangan. Yogyakarta: BPFE.

Antonio, Muhammad Syafii (2001), Bank Syari'ah: Dari Teori ke Praktek, (Gema Insani Press bekerja sama dengan Yayasan Tazkia Cendekia) 
Wild, John J., K. R. Subramanyam, dan Robert F. Halsey. 2008. Analisis Laporan Keuangan, Buku Satu, Edisi Kedelapan. Diterjemahkan oleh Yanivi S. Bachtiar dan S. Nurwahyu Harahap. Jakarta: Salemba Empat.

Undang-Undang RI No. 21 tahun 2008 tentang Perbankan Syariah

www.brisyariah.co.id 